\title{
Development of Sustainable Concrete using Ceramic Waste as Partial Replacement with Cement
}

\author{
Haitham S. Darwesh ${ }^{\mathrm{a}}$, Mohammed Alaa Tabanaj ${ }^{\mathrm{a}}$, Kiran Kumar Poloju ${ }^{\mathrm{a}}$
}

\begin{abstract}
Nowadays in developed and developing countries, disposal of ceramic waste is becoming one of the major problem. According to varies research done on the ceramic waste, the percentage of waste generated from the production is about 15-30\%, further to the waste introduced from the construction field. In addition, reuse or recycle of ceramic waste is negligible. In this research an attempt was done to reuse the ceramic waste in concrete, the cement was partially replaced with the ceramic waste with proportion of $10 \%, 20 \%$ and $30 \%$ from the cement weight for M25 grade concrete. The ceramic waste was collected from ceramic factories as well as from construction sites. The results illustrate that the compressive strength of the concrete with ceramic waste is greater than the compressive strength in the conventional concrete. The main advantages of reuse ceramic wastes as a building material are reduce the cost of concrete (economic factor) and minimize environmental impact (environmental factor). This is one of the alternative method for implementing the sustainable concept in the construction field
\end{abstract}

Keywords: ceramic waste, sustainability, concrete, Oman, environment

\section{Introduction}

Since the beginning of the industrial revolution, the biggest challenge faces the human being is to preserve the environment by minimizing the negative effects and conserving our natural resources. Therefore, all industrial sectors and particularly construction industrial trend to reduce the dependence on the natural resources as well as minimize the production waste. Nowadays, the sustainable concept is mandatory requirement in the construction field. One of that is to use the waste of the other industries as a building material. The aim of this project is to use ceramic waste as a partial replacement of cement in concrete. This will lead to reduce the cost as well as protect the environment. According to Pacheco: "the production of cement

Table: (2). Chemical properties of ceramic waste

\begin{tabular}{|c|c|}
\hline Materials & ceramic powder \% \\
\hline $\mathrm{SiO} 2$ & 63.28 \\
\hline $\mathrm{AI} 2 \mathrm{O} 3$ & 18.28 \\
\hline $\mathrm{Fe} 2 \mathrm{O} 3$ & 4.35 \\
\hline $\mathrm{CaO}$ & 4.47 \\
\hline $\mathrm{MgO}$ & 0.75 \\
\hline $\mathrm{P} 2 \mathrm{O} 5$ & 0.17 \\
\hline $\mathrm{K} 2 \mathrm{O}$ & 2.19 \\
\hline $\mathrm{Na} 2 \mathrm{O}$ & 0.74 \\
\hline $\mathrm{SO} 3$ & 0.11 \\
\hline $\mathrm{CL}$ & 0.006 \\
\hline
\end{tabular}

requires high energy input (850 kcal per kg of clinker) and implies the extraction of large quantity of raw material from the earth (1.7 tons of rock to produce 1 ton of clinker). On the other hand, the production of one ton of cement generate 0.55 ton of chemical $\mathrm{CO} 2$ and requires an additional 0.39 ton of $\mathrm{CO} 2$ in fuel emission, accounting for a total of 0.94 ton of CO2." (Pacheeo. F\& Jalali. S. ,2011) Therefore, use the ceramic waste as a replacement of cement is feasible as well as it will significantly contribute in preserve natural resources, save energy, reduce the cost of deposition ceramic waste, increase vacant land, minimize environment pollution and reduce the cost since $45 \%$ of concrete cost is cement cost.

\section{MATERIAL USED \& MiX PROPORTION:}

Generally, Concrete is composition of Cement, fine aggregate, coarse aggregate and water (Domone P \& Illston. J., 2010). The sustainable concrete or green concrete is the concrete that contain waste product. Hence, ceramic waste used in this study.in addition to concrete material. Table (1) shows the specific gravity of the materials used for doing this study. The mix proportion used in this research was 1:1:2 as shown on Appendix (1).

\section{A. Cement}

Ordinary Portland cement was used in this investigation. The specific gravity fineness modulus and workability of concrete were the only test done on the cement to check its quality.

\section{B. Ceramic waste powder}

Through the processes of producing ceramic tiles in ceramic industry considered amount of waste is produced around $15-30 \%$ of total production. the ceramic waste were collected. Then crushed physically (without changing of chemical composition). Then ceramic sample sieved from 90-micron sieve. and finally used as partial cement replacement. The composition of ceramic tile is listed down on Table (2). In addition, as the chemical composition of ceramic doesn't change (the change is negligible), hence, this composition can be considered also for ceramic powder (Askeland.D.R\&Fulay.P.P,Wright .W.J,2011).

\section{AGGREGATE}

The aggregate sample where collected from nearby college lab. Only fineness modulus, bulk density, specific gravity and Water absorption were tested. Table (3) shows the results of these experiment

Table (1): Materials' specific gravity

\begin{tabular}{|c|c|c|}
\hline Materials & Specific Gravity & IS code \\
\hline Cement & 3.15 & IS: $8112-1989$ \\
\hline Ceramic waste & 3.1 & - \\
\hline Fine aggregate & 2.62 & IS: 383 \\
\hline C. Aggregate & 2.82 & IS: 383 \\
\hline
\end{tabular}


Table (3): Aggregate properties

\begin{tabular}{|c|c|c|}
\hline Property & F. agg & C. agg \\
\hline Fineness modulus & 3.1 & 7.5 \\
\hline Bulk density $(\mathrm{gm} / \mathrm{cc})$ & 1759 & 1739 \\
\hline & & \\
Water absorption \% & 1.15 & 1.79 \\
\hline
\end{tabular}

D. Water

Portable water available on the lab of the college was used in the mixture

\section{Experimental Program}

To assess the feasibility of using ceramic waste as a replacement of cement in the concrete in terms of compressive strength, the mix proportions shown in appendix (2) were used to prepare four different type of concrete normal, $10 \%$ ceramic replacement, $20 \%$ percent ceramic replacement and $30 \%$ ceramic replacement with a water cement ration of 0.45 .36 molds of size $150 \mathrm{~mm} * 150 \mathrm{~mm} * 150 \mathrm{~mm}$ were prepared and cast with varies type of concrete nine for each. The molds with concrete were left for 24 hours before de-molded. The water curing process was done and the compressive strength test using compressive strength testing machine performed according to

Table (6): C. Strength at 7, 14 and 28 days

\begin{tabular}{|c|c|c|c|}
\hline \multirow{2}{*}{ Concrete type } & \multicolumn{3}{|c|}{ Average C. Strength $\mathbf{N} / \mathbf{m m}^{\mathbf{2}}$} \\
\cline { 2 - 4 } & $\mathbf{7}$ days & $\mathbf{1 4}$ days & $\mathbf{2 8 ~ d a y s}$ \\
\hline $\mathrm{N}$ & 26 & 31.5 & 33 \\
\hline $\mathrm{CW} 1$ & 26.5 & 31.7 & 33.3 \\
\hline $\mathrm{CW} 2$ & 26.9 & 31.8 & 33.4 \\
\hline CW3 & 27 & 32 & 34 \\
\hline
\end{tabular}

the following,

- 12 casts, three form each type was tested after 7 days of water curing and average compressive strength calculated.

- 12 casts, three form each type was tested after 14 days of water curing and average compressive strength calculated.

- 12 casts, three form each type was tested after 28 days of water curing and average compressive strength calculated.

\section{Economic Factor}

The challenge nowadays is not only focus on developing technologies that aim to reduce the human activity impact on the environment. The exact challenge is to provide sustainable technologies that consider environment, social and economy at same time. From this, it is clear that the economic factor is a priority and without considering economic factor in any sort of project will lead definitely to destroy the project. Hence, the economic factor of using ceramic waste was studied and the result shows that using of ceramic waste in producing concrete will reduce the concrete production cost. Tables $(4 \& 5)$ shows the cost reduction

Table (4): materials cost

\begin{tabular}{|c|c|c|}
\hline Sr. No & Materials & Rate (RO/Ton) \\
\hline 1 & OPC cement & 40 \\
\hline 2 & F. Aggregate & 4.5 \\
\hline 3 & C. Aggregate & 5.2 \\
\hline 4 & ceramic waste & 0 \\
\hline
\end{tabular}

\section{Result}

\section{A. Compressive Strength}

The result, as expected, shows that the compressive strength for concrete with replacement of ceramic waste shows slightly increase in the compressive strength .so, the result shows that the optimum percentage to replace cement with ceramic waste is $30 \%$. As it shows the best compressive strength of $34 \mathrm{Mpa}$ Table (5) present the compressive strength for the mixes through (7, 14, 28 Day). Overall as the appendix (1) represent the compressive strength the variation in compressive strength between $\mathrm{CW} 1, \mathrm{CW} 2, \mathrm{CW} 3$ and the conventional concrete $(\mathrm{N})$ is very less. Therefore, using ceramic waste can give same performance of normal concrete or even better.

It is clear from the result that the compressive strength increase and it is $34 \mathrm{Mpa}$ for $30 \%$ replacement. In addition, using ceramic waste can reduce the cost up to $16 \%$ that makes this process of replace cement by ceramic waste beneficial and advantageous from all sides, environment, economic, performance and material efficiency. Hence, many sustainable factors are covered so that this concrete will be sustainable concrete

\section{Conclusion:}

Based on this investigation, it is feasible to use the ceramic waste as cement replacement in grade M25 concrete. since, the compressive strength slightly increases with the concrete represent up to $30 \%$ ceramic waste form cement weight, the compressive strength of normal concrete was $33 \mathrm{Mpa}$ after 28 days whereas it was $34 \mathrm{Mpa}$ for concrete with ceramic waste after the same period. Furthermore, the concrete consists $30 \%$ of ceramic waste as replacement of cement is saving $16 \%$ from the total cost of the convention concrete as shown in table (5) Therefore, it is the most effective method to implement the sustainable concept in construction field, preserve the environment, conserve the natural resources and minimize the production cost. It is recommended for future study to test the compressive strength for the range of $25-35 \%$ so that the optimum value will be more accurate. It is also recommended to test the other properties of concrete for instance durability, tensile strength.to check the quality of concrete mix. 


\section{References}

D. Raval. A, N.Patel. I, Pitroda. J. (2013) 'Ceramic Material'. Use of ceramic powder as a partial replacement of cement 3 (2), 155-167

Pacheeo. F, Jalali. S. (2011) 'Materials and structure'. Compressive strength and durability properties of ceramic wastes based concrete 44 (1), 155-167

Pacheeo. F, Jalali. S. (2010) 'Construction and Building Materials'. Reusing ceramic wastes in concrete 1 (24), 832-838

Domone P and Illston. J. (2010), Construction Material Their Nature and Behavior, (4th ed), New York: Spon Press.
Askeland.D.R,Fulay.P.P,Wright .W.J(2011)' the science and engineering of material ' 6 th edition, USA ,Cengage learning $<<\mathrm{http}: / /$ home.ufam.edu.br/berti/nanomateriais/0495296023Mat erialsEnginee.pdf $>>$

8- Appendix

Appendix (1): Mix design proportions (M25)

\begin{tabular}{|c|c|c|c|c|c|c|}
\hline \multirow{2}{*}{$\begin{array}{c}\text { Sr. } \\
\text { No }\end{array}$} & \multirow{2}{*}{ Concrete type } & \multicolumn{5}{|c|}{ Mix proportions } \\
\cline { 2 - 6 } & $\begin{array}{c}\text { w/c } \\
\text { ratio }\end{array}$ & cement & F. A & C.A & C.W \\
\hline 1 & NC & 0.45 & 1 & 1 & 2 & 0 \\
\hline 2 & CW1 & 0.45 & 0.9 & 1 & 2 & 0.1 \\
\hline 3 & CW2 & 0.45 & 0.8 & 1 & 2 & 0.2 \\
\hline 4 & CW3 & 0.45 & 0.7 & 1 & 2 & 0.3 \\
\hline
\end{tabular}

Appendix (2): compressive strength vs days

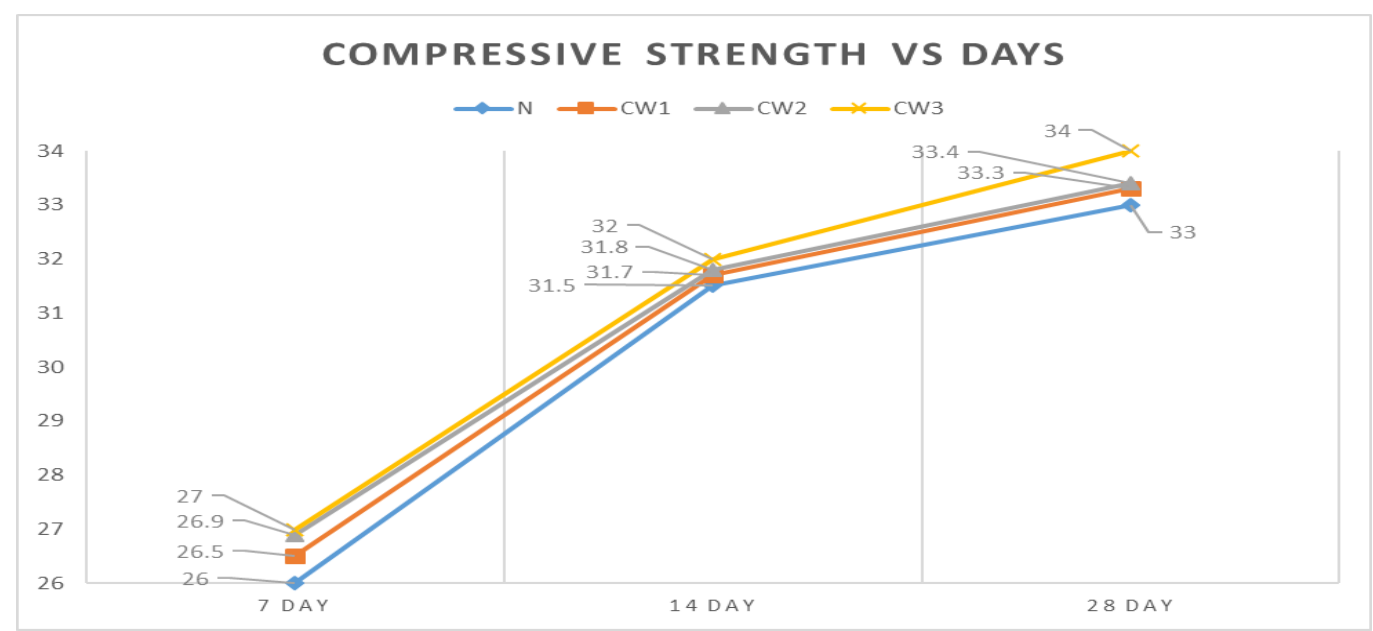

